\title{
БОТАНІКА
}

УДК 630*182.51:630*231.1:582.632.1

doi: $10.25128 / 2078-2357.21 .1-2.1$

\author{
О. Л. ПОРОХНЯВА, В. М. ГРАБОВИЙ, Г. І. МУЗИКА, Ю. О. РУМ'ЯНКОВ
}

Національний дендрологічний парк «Софіївка» НАН України

вул. Київська, 12a, Умань, Черкаська область, 20300

e-mail: porokhniava@gmail.com

\section{ВIКОВА СТРУКТУРА ПІДРОСТУ CARPINUS ВETULUS L. У КУЛЬТУРФІТОЦЕНОЗАХ НАЦІОНАЛЬНОГО ДЕНДРОЛОГІЧНОГО ПАРКУ «СОФІЇВКА» НАН УКРАЇНИ}

Здійснено аналіз природного поновлення аборигенних рослин у культурфітоценозах Національного дендрологічного парку «Софіївка» НАНУ. У результаті обстеження дендрологічної структури виявлено життєздатний підріст головних структуроутворюючих видів під наметом деревостану. 3'ясовано перспективність заміни сенільних рослин Carpinus betulus L. молодим поколінням. Підріст C. betulus складає 4,5 \% від загальної кількості життєздатного підросту на пробних площах, що значно менше порівняно 3 A.platanoides $64,5 \%$ та A. campestre - 20,7\%. Відмічено наявність достатньої кількості життєздатного віргінільного та молодого генеративного підросту C. betulus, що в майбутньому здатний сформувати деревостан. Вчасне видалення природного поновлення агресивних аборигенних та інтродукованих видів сприятиме створенню комфортних умов для росту і розвитку молодого покоління C. betulus.

Ключові слова: Carpinus betulus L., аборигенний вид, деревостан, підріст, онтогенетичний стан.

Культурфітоценоз не стабільна структура, яка потребує регулярного моніторингу та догляду. Розпад насаджень відбувається під впливом несприятливих умов середовища та у зв'язку з досягненням біологічної межі онтогенетичного розвитку. Питання збереження композиційного задуму в історичних парках під час реконструкції насаджень $\epsilon$ головним завданням дендрологів. Використання аборигенних видів для створення та реконструкції садово-паркових об'єктів є перспективним 3 ряду причин: високий ступінь адаптації рослин до умов навколишнього середовища, дешевизна та доступність садивного матеріалу, а також, завдяки імітації природного фітосередовища, комфортний психоемоційний вплив на рекреантів. Важливим джерелом матеріалу для реконструкційних робіт виступає молоде покоління поширених у деревостані рослин. Позитивне значення для природнього поновлення має життєздатний підріст у віргінільному стані $[10,15]$. На успішність росту і розвитку підросту впливає піднаметова освітленість, товщина гумусового горизонту, термо- та омброклімат, вологість, кислотність та засоленість грунту, а також наявний вміст азоту та карбонатів $[1,10,11,12]$.

Рослини виду Carpinus betulus L. входять у переважну більшість листяних насаджень Національного дендрологічного парку «Софіївка»НАНУ, беруть участь у формуванні деревостанів разом із Quercus robur L., Acer platanoides L., Acer campestre L. та Fraxinus excelsior L. У зв'язку з природним відпадом рослин C. betulus та активним зниженням їх життєздатності, що було виявлено нами за останні 10 років, питання перспективи самовідновлення виду на території парку є актуальним.

ISSN 2078-2357. Наук. зап. Терноп. нац. пед. ун-ту. Сер. Біол., 2021, Т. 81, № 1-2 
Об’ єктом наукового дослідження був підріст $C$. betulus в умовах НДП «Софіївка» НАН України. Предмет дослідження - вікова структура підросту C. betulus.

Мета роботи полягала в 3'ясуванні вікової структури підросту C. betulus в умовах культурфітоценозів НДП «Софіївка» НАН України. Для вирішення цього питання було визначено кількісний та віковий склад підросту $C$. betulus та інших аборигенних рослин. На основі отриманих результатів було спрогнозовано перспективність заміни сенільних рослин C. betulus молодими, а також запропоновано практичні рекомендації з догляду за підростом C. betulus в умовах НДП «Софіївка» НАН України.

\section{Матеріал і методи досліджень}

Для обчислення підросту закладали пробні площі у вигляді кола діаметром 50 м. Опис дендрологічної структури виконували на однорідних (гомогенних) ділянках рослинності, які були відібрані у ході рекогносцирувальної екскурсії [5]. Обрані ділянки типові за інтенсивністю догляду, подібні за рельєфом, мікрокліматичними та грунтовими умовами. Під час обстеження визначали: склад деревостану, кількість підросту, вид, онтогенетичний стан [7, 9, 13]. Видові назви встановлювали у відповідності з визначниками номенклатурних назв рослин $[4,14,15]$.

\section{Результати досліджень та їх обговорення}

Аналіз вікової структури - обов'язковий етап фітоценотичних досліджень садово-паркових культурфітоценозів. Цей показник характеризує життєвість окремих рослин та стійкість угрупування в цілому. Популяція представлена великою кількістю генеративних та прегенеративних особин, згідно класифікації Т. А. Работнова (1983), є нормальною, тобто вид перспективний у фітоценозі, володіє здатністю до самовідновлення та активного поширення [9]. Якщо вид в угрупуванні представлений старими генеративними та сенільними рослинами, це вказує на деградацію та деструкцію популяції виду. Такі популяції називаються регресивними, а штучні угрупування за їх участю потребують реконструкції та оптимізації.

Сприятливими умовами для природного поновлення деревних рослин $\epsilon$ наявність життєздатного насіння, стабільна вологість грунту, відсутність різких коливань температур, низьке задерніння грунту світлолюбними трав'янистими рослинами, велика кількість мікоризоутворювачів в поверхневому шарі грунту. Негативну дію чинять низький рівень піднаметового освітлення, агресивний алелопатичний вплив, висока конкуренція 3 материнськими рослинами, щільна вологонепроникна підстилка [2].

Для створення нових та реконструкції існуючих історичних насаджень доцільно використовувати довговічні та стійкі до несприятливих погодно-кліматичних умов аборигенні рослини. Функціонування таких садово-паркових об'єктів характеризується високою економічною ефективністю та спрощеним подальшим доглядом [6].

Основою дендрологічної складової НДП «Софіївка» $\epsilon$ покритонасінні аборигенні рослини, зокрема $C$. betulus, який займає одне з головних місць. Для відображення основних тенденцій природного поновлення C. betulus, було закладено пробні площі в кварталах, де зосереджена найбільша кількість аборигенних рослин (рис. 1, табл. 1).

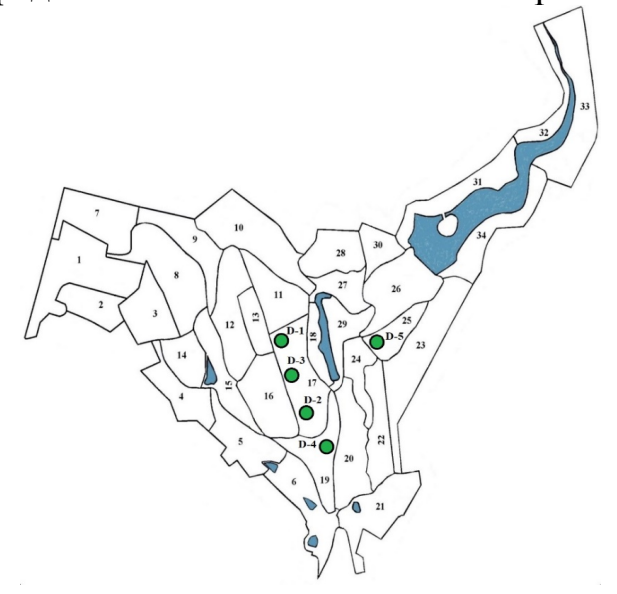

Рис. 1. Розміщення пробних площ на території НДП «Софіївка» НАН України (D-1- D-5 - пробні площі). 
Дендрологічна структура пробних площ

\begin{tabular}{|c|c|c|}
\hline $\begin{array}{l}\text { Пробна } \\
\text { Площа }\end{array}$ & Склад деревостану & Підріст \\
\hline D-1 & $4 Г з 3$ Яз3Клг+Дз+Лс+Взг & $\begin{array}{c}\text { Acer platanoides L., Fraxinus excelsior L., Acer } \\
\text { tataricum L., Carpinus betulus L., Tilia cordata Mill., } \\
\text { Ulmus laevis Pall. }\end{array}$ \\
\hline D-2 & 6Гз2Клг1Яз1Дз+Лс+Клп & $\begin{array}{c}\text { Acer platanoides L., Carpinus betulus L., Tilia } \\
\text { cordata Mill., Ulmus laevis Pall. }\end{array}$ \\
\hline D-3 & 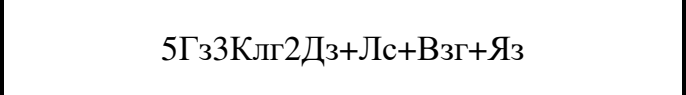 & $\begin{array}{l}\text { Acer platanoides L., Acer campestre L., Fraxinus } \\
\text { excelsior L., Carpinus betulus L., Tilia cordata Mill. }\end{array}$ \\
\hline D-4 & 4 Яз2Дз2Сч1Бер1Гз+Взш+Взг+Клп+Глк+Лпс & $\begin{array}{l}\text { Acer platanoides L., Acer campestre L., Ulmus glabra } \\
\text { Huds., Fraxinus excelsior L., Carpinus betulus L. }\end{array}$ \\
\hline D-5 & 4Яз3Клг2Взш1Лс+Гз & $\begin{array}{c}\text { Acer campestre L., Acer platanoides L., Fraxinus } \\
\text { excelsior L., Carpinus betulus L. }\end{array}$ \\
\hline
\end{tabular}

Деревостан на закладених пробних площах сформований аборигенними видами, за виключенням ділянки D-4, на якій ростуть сенільні екземпляри Pinus nigra subsp. pallasiana (Lamb.) Holmboe. Під наметом відмічено життєздатний самосів U. laevis, U. glabra, C. betulus, A. platanoides, A.campestre, A. tataricum, $T$. cordata та $F$. excelsior у різних онтогенетичних станах - від проростків до молодих генеративних рослин (рис. 2, табл. 2).

70

60

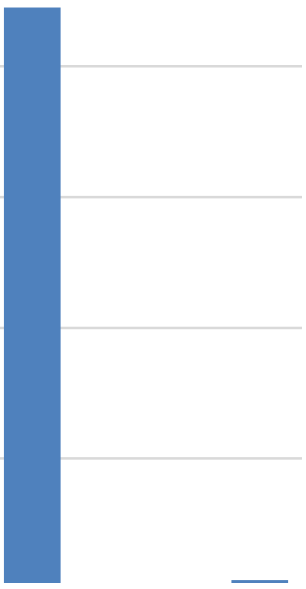

Рис. 2. Видовий склад підросту на пробних площах.

Результати аналізу видового складу підросту вказують на успішне поновлення аборигенних видів у культурфітоценозах парку. Найбільшу кількість підросту відмічено у A.platanoides - 64,5 \% від сумарної кількості підросту на пробних площах. Рослини виду A.platanoides характеризуються стабільним регулярним плодоношенням, високою насінною продуктивністю та рясною появою сходів.

На другому місці за часткою участі у підрості знаходиться A. campestre - 20,7\%, його поширенню сприяє висока тіневитривалість рослин та інтенсивне вегетативне розмноження, підріст цього виду може тривалий час існувати в підліску, зберігаючи високу життєздатність.

Третє місце $-5,6 \%$ займає підріст $F$. excelsior. На успішність поновлення цього виду впливає щільність трав'яного покриття, проростки не витримують конкуренції 3 боку трав'янистої рослинності. 
A. platanoides, A. campestre та $F$. excelsior активно поширюються, легко займають вільну площу, завдяки особливостям будови насіння можуть проростати на значній відстані від материнських рослин.

C. betulus складає 4,5 \% від загальної кількості підросту на пробних площах, зосереджений переважно під наметом генеративних рослин. Не зважаючи на те, що рослини цього виду займають значне місце у деревостані, кількість підросту значно поступається A. platanoides та A. campestre.

Частка участі у підрості U. laevis, U. glabra, A. tataricum та $T$. cordata незначна та становить менше $3 \%$ для кожного виду.

Таблиия 2

Розподіл підросту за онтогенетичним станом

\begin{tabular}{|c|c|c|c|c|c|c|c|c|}
\hline \multirow[b]{2}{*}{ 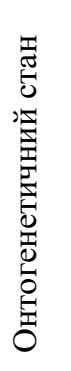 } & \multicolumn{8}{|c|}{ Частка у підрості, \% } \\
\hline & 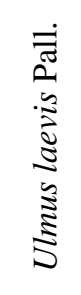 & $\begin{array}{c}0 \\
0 \\
0 \\
0 \\
0 \\
0 \\
0 \\
0 \\
3 \\
0 \\
5\end{array}$ &  & 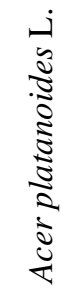 & 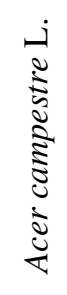 & 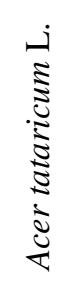 & 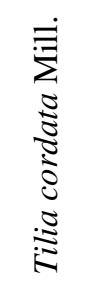 & 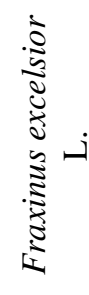 \\
\hline $\mathrm{p}$ & 0,5 & 0,8 & 2,1 & 28,3 & 9,4 & 0,2 & 0,4 & 2,2 \\
\hline $\mathrm{j}$ & 0,2 & 0,6 & 1,2 & 15,1 & 3,2 & 0,1 & 0,3 & 1,4 \\
\hline $\mathrm{im}$ & 0,1 & 1,0 & 0,6 & 11,0 & 2,6 & 0,1 & 0,2 & 0,9 \\
\hline $\mathrm{v}$ & $<0,1$ & - & 0,5 & 10,0 & 5,4 & - & 0,2 & 1,1 \\
\hline $\mathrm{g}_{1}$ & $<0,1$ & - & 0,1 & 0,2 & 0,2 & - & $<0,1$ & $<0,1$ \\
\hline
\end{tabular}

Найбільшу кількість проростків виявлено у A.platanoides - 28,3\%, а найменшу - у A.tataricum - 0,2 \%. Проростки, ювенільні та іматурні рослини були відмічені у всіх досліджуваних видах, однак у U. glabra та A. tataricum не знайдено віргінільних та молодих генеративних рослин. Найвищу перспективність природного поновлення мали A.platanoides (v-10,0\%; $\mathrm{g}_{1}-0,2 \%$ ) та A. campestre (v - 5,4\%; $\left.\mathrm{g}_{1}-0,2 \%\right)$. Середня перспективність у F. excelsior (v $\left.-1,1 \% ; \mathrm{g}_{1}-<0,1 \%\right)$ та C. betulus (v $\left.-0,5 \% ; \mathrm{g}_{1}-0,1 \%\right)$. Найменшу частку віргінільного та молодого генеративного підросту мали $T$. cordata (v $\left.-0,2 \% ; \mathrm{g}_{1}-<0,1 \%\right)$ та U. laevis $\left(\mathrm{v}-<0,1 \%\right.$; $\left.\mathrm{g}_{1}-<0,1 \%\right)$.

Питання збереження дендрологічної структури в історичних парках потребує виконання ряду агротехнічних заходів, спрямованих на забезпечення декоративності та довговічності рослинних угрупувань. Культурфітоценози з участю C. betulus $є$ основою історичної частини НДП «Софіївка», ці насадження є одними з небагатьох самовідновлюваних у парку, адже аборигенні види мають вищий адаптаційний потенціал та здатні до успішного поновлення. Контроль за співвідношенням видового та кількісного складу підросту, вчасні раціональні санітарні та ландшафтні рубки створюватимуть оптимальні умови для росту і розвитку підросту C. betulus.

\section{Висновки}

В умовах НДП «Софіївка» НАН України для аборигенних видів характерне успішне природне поновлення. Виявлено життездатний підріст U. laevis, U. glabra, C. betulus, A. platanoides, A. campestre, A. tataricum, $T$. cordata та $F$. excelsior.

C. betulus - важливий структуроутворюючий вид, успішність природного поновлення якого має безпосередній вплив на стабільність рослинних угрупувань парку. Загальна кількість підросту C. betulus складає 4,5 \%, що значно менше, порівняно з A. platanoides $(64,5 \%)$ та A. campestre $(20,7 \%)$.

Перспективність природного поновлення рослин виду $C$. betulus за кількісною та віковою характеристикою подібна до F. excelsior. Кількість віргінільних рослин становить 0,5\%, а

ISSN 2078-2357. Наук. зап. Терноп. нац. пед. ун-ту. Сер. Біол., 2021, T. 81, № 1-2 11 
молодих генеративних - 0,1\%, порівняно з A.platanoides та A. campestre отримані показники у понад 10 разів менші для віргінільних та у 2 рази - для молодих генеративних рослин, що вказує на слабку конкурентоздатність підросту C. betulus.

Регулярне видалення надлишкової кількості більш агресивніших рослин A.platanoides, A. campestre та $F$. excelsior $\epsilon$ основним заходом зі створення оптимальних умов для росту і розвитку природного поновлення $C$. betulus.

1. Алексеев В. А. Световой режим леса. Ленинград : Наука, 1975. 228 с.

2. Атрохин В. Г., Кузнецов Г. В. Лесоводство. Москва : Агропромиздат, 1989. 231 с.

3. Заячук В. Я. Дендрологія. Голонасінні : навч. посіб. Львів : ТзОВ «Фірма «Камула», 2005. 176 с.

4. Заячук В. Я. Дендрологія. Покритонасінні : навч. посіб. Львів : ТзОВ «Фірма «Камула», 2004. 408 с.

5. Кузьмішина I. І., Коцун Л. О., Коцун Б. Б., Фішук О. С. Фітоценологія : методичні рекомендації до лабораторних занять для студентів спеціальностей 091 «Біологія», 014 «Середня освіта (Біологія)» біологічного факультету : 2-ге видання, доповнено і перероблено. Луцьк : Вежа-Друк, 2019. 83 с.

6. Масальський В. П., Кузнєцов С. І. Аборигенна дендрофлора покритонасінних - основа паркобудування в Лісостепу України. Науковий вісник НЛТУ України. 2018. Т. 28, № 8. С. 14-18. DOI: https://doi.org/10.15421/40280802.

7. Определитель высших растений Украины / за ред. Д. Н. Доброчаева, М. И. Котов, Ю. Н. Прокудин и др. 2 изд. стереот. Киев : Фитосоциоцентр, 1999. 548 с.

8. Работнов Т. А. Жизненный цикл многолетних травянистых растений в луговых ценозах. Труды БИН АН СССР. Москва-Ленинград : Издательство АН СССР, 1950. Вып. 6. Сер. 3. Геоботаника. С. $7-$ 204.

9. Работнов Т. А. Фитоценология : 2- е изд. Москва : Издательство Московского университета, 1983. $296 \mathrm{c}$.

10. Рыжков О. В. Состояние и развитие дубрав Центральной лесостепи. Тула : ЦЧГЗ, 2001. 182 с.

11. Скляр В. Г. Екологічні зв'язки дрібного підросту деяких широколистяних порід. Украйнський ботанічний журнал. 2002. Том 59, № 5. С. 589-597.

12. Турчин Т. Я. Естественные степные дубравы Донского бассейна и их восстановление. Москва : ВНИИЛМ, 2004. $312 \mathrm{c}$.

13. Уранов А. А. Возрастной спектр фитоценопопуляций как функция времени и энергетических волновых процессов. Биологические науки. 1975. № 2. С. 7-34.

14. Ценопопуляции растений : основные понятия и структура / ред. О. В. Смирновой. Москва : Наука, 1976. $214 \mathrm{c}$.

15. Coates K. D. Tree recruitment in gaps of various size, clearcuts and undisturbed mixed forest of interior British Columbia, Canada. Forest Ecology and Management. 2002. № 155. P. 387-398.

\section{References}

1. Alekseev V. A. Svetovoy rezhim lesa. Leningrad : Nauka, 1975. 228 s. [in Russian]

2. Atrokhin V. G., Kuznetsov G. V. Lesovodstvo. Moskva : Agropromizdat, 1989. 231 s. [in Russian]

3. Zaiachuk V. Ya. Dendrolohiia. Holonasinni: navch. posib. Lviv : TzOV «Firma «Kamula», 2005. 176 s. [in Ukrainian]

4. Zaiachuk V. Ya. Dendrolohiia. Pokrytonasinni: navch. posib. Lviv : TzOV «Firma «Kamula», 2004. 408 s. [in Ukrainian]

5. Kuzmishyna I. I., Kotsun L. O., Kotsun B. B., Fishchuk O. S. Fitotsenolohiia : metodychni rekomendatsii do laboratornykh zaniat dlia studentiv spetsialnostei 091 «Biolohiia», 014 «Serednia osvita (Biolohiia)» biolohichnoho fakultetu : 2-he vydannia, dopovneno i pererobleno. Lutsk : Vezha-Druk, 2019. 83 s. [in Ukrainian]

6. Masalskyi V. P., Kuznietsov S. I. Aboryhenna dendroflora pokrytonasinnykh - osnova parkobuduvannia v Lisostepu Ukrainy. Naukovyy visnyk NLTU Ukrainy. 2018. T. 28, No 8. S. 14-18. DOI: https://doi.org/10.15421/40280802. [in Ukrainian]

7. Opredelitel vysshikh rasteniy Ukrainy / za red. D. N. Dobrochaeva, M. I. Kotov, Iu. N. Prokudin i dr. 2 izd. stereot. Kiev : Fitosotsiotsentr, 1999. 548 s. [in Russian]

8. Rabotnov T. A. Zhiznennyy tsikl mnogoletnikh travianistykh rasteniy v lugovykh tsenozakh. Trudy BIN AN SSSR. Moskva-Leningrad : Izdatelstvo AN SSSR, 1950. Vyp. 6. Ser. 3. Geobotanika. S. 7-204. [in Russian]

9. Rabotnov T. A. Fitotsenologiia : 2- e izd. Moskva : Izdatelstvo Moskovskogo universiteta, 1983. 296 s. [in Russian]

12 ISSN 2078-2357. Наук. зап. Терноп. нац. пед. ун-ту. Сер. Біол., 2021, T. 81, № 1-2 
10. Ryzhkov O. V. Sostoianie i razvitie dubrav Tsentral'noy lesostepi. Tula : TsChGZ, 2001. 182 s. [in Russian]

11. Skliar V. H. Ekolohichni zviazky dribnoho pidrostu deiakykh shyrokolystianykh porid. Ukrains'kyy botanichnyi zhurnal. 2002. Tom 59, No 5. S. 589-597. [in Ukrainian]

12. Turchin T. Ia. Estestvennye stepnye dubravy Donskogo basseyna i ikh vosstanovlenie. Moskva : VNIILM, 2004. 312 s. [in Russian]

13. Uranov A. A. Vozrastnoy spektr fitotsenopopuliatsiy kak funktsiia vremeni i energeticheskikh volnovykh protsessov. Biologicheskie nauki. 1975. No 2. S. 7-34. [in Russian]

14. Tsenopopuliatsii rasteniy : osnovnye poniatiia i struktura / red. O. V. Smirnovoy. Moskva : Nauka, 1976. 214 s. [in Russian]

15. Coates K. D. Tree recruitment in gaps of various size, clearcuts and undisturbed mixed forest of interior British Columbia, Canada. Forest Ecology and Management. 2002. № 155. P. 387-398.

O. L. Porokhniava, V. M. Hrabovyi, H. I. Muzyka, Y. O. Rumiankov

National Dendrological Park «Sofiyivka» of NAS of Ukraine

AGE STRUCTURE OF THE YOUNG GROWTH OF CARPINUS BETULUS L. IN THE ARTIFICIAL PHYTOCENOSES OF NATIONAL DENDROLOGICAL PARK «SOFIYIVKA» OF NAS OF UKRAINE

The issue of preserving the dendrological structure in historical parks requires the implementation of a number of agronomic measures aimed at ensuring the decorative and durability of plant communities. The plants of Carpinus betulus L. are included in the vast majority of deciduous plantations of the National Dendrological Park «Sofiyivka» of NASU, form the stands with the participation of Quercus robur L., Acer platanoides L., Acer campestre L. and Fraxinus excelsior L. The question of self-recovery of $C$. betulus plants in the park is relevant in connection with natural waste and active reduction of its viability identified over the past 10 years. The analysis of the success of natural regeneration of aboriginal plants in the cultural phytocenoses of the National Dendrological Park «Sofiyivka» of NASU has been conducted. As a result of the survey of the dendrological structure, viability of the young growth of the main structure-forming species under the stand was revealed. The prospects of replacing senile plants of $C$. betulus with the younger generation have been outlined. The young growth of $C$. betulus is $4.5 \%$ of the total number of viable undergrowth in the test plots, which is significantly less compared to A. platanoides $-64.5 \%$ and A. campestre $-20.7 \%$. There is a sufficient number of viable virginile and young generative plants of $C$. betulus, which in future is able to form a stand. Prospects for natural regeneration of plants of the $C$. betulus species are average, similar in quantitative and age characteristics to plants of the Fraxinus excelsior L. The number of virginile plants is $0.5 \%$, and young generative $-0.1 \%$, compared with A. platanoides and A. campestre, the results are more than 10 times lower for virginile and 2 times - for young generative plants, which indicates a weak competitiveness of the young growth of $C$. betulus. Artificial phytocenoses with the participation of $C$. betulus are one of a few self-regenerating species in the park, as aboriginal species have a higher adaptive potential and are capable of successful renewal. Control over the ratio of species and quantitative composition of undergrowth, timely rational sanitary and landscape felling will create optimal conditions for growth and development of the young growth of $C$. betulus. Regular removal of aggressive plants of A. platanoides, A. campestre and F. excelsior will help preserve the existing structure of the stand in the historic part of the NDP «Sofiyivka».

Keywords: Carpinus betulus L., aboriginal species, stand, the young growth, ontogenetic state.

Надійшла 10.03.2021. 